Pall Rikhardsson

Accounting for Health and Safety costs: Review and comparison of selected methods

Management Accounting

Research Group

Department of Accounting,

Finance and Logistics 


\title{
Accounting for Health and Safety costs: Review and comparison of selected methods
}

Pall Rikhardsson

par@asb.dk

Aarhus School of Business

\begin{abstract}
A part of the emerging sustainability management accounting is corporate health and safety performance. One performance dimension is the costs of occupational accidents in companies. The underlying logic for calculating these costs is that if occupational accidents are prevented then these costs could be avoided. This chapter presents and discusses selected methods for calculating the costs of occupational accidents. The focus is on presenting the characteristics of each method and disclosing the benefits and drawbacks of each method.
\end{abstract}

\section{I ntroduction}

Management accounting could be defined as the process of identification, measurement, accumulation, analysis, preparation, interpretation, and communication of financial and non-financial information used by management to plan, evaluate, and control within an organization and to assure appropriate use of and accountability for its resources. For other definitions see e.g. Atkinson (et al. 2004).

Management accounting as a corporate function has changed over the years in a number of ways (see e.g. Neely 2003; Read 2003). First of all it has moved from being a purely controlling and reporting function to a value creating function delivering information and analysis to other functions in the company. Secondly, with the advent of ERP (Enterprise Resource Planning) systems many of the manual processes have been automated so management accountants can allocate their time to analyzing, planning and supporting business units (Poston \& Grabski 2001). Thirdly, management accountants do no longer only focus on financial numbers but also non-financial information such as those necessary to make a Balanced Scorecard function or implement Business Process reengineering projects (Kaplan \& Norton 1997). Finally, management accountants have roles to play in fields like project evaluations, strategic planning and stakeholder relations thus extending the reach and influence of management accounting techniques and methods. An example of a field in which management accounting has also come to play a role is environmental management. Environmental management accounting as defined by e.g. Bennett (et al 1998) and Bartolomeo (et al. 1997) focuses on supporting management decision making regarding issues such as environmental costs, environmental investment evaluations and environmental taxes by the identification, measurement, accumulation, analysis, preparation, interpretation, and communication of financial and non-financial environmental information.

As sustainability becomes the benchmark for societal development it could be argued that managers need information about other sustainability issues than just the environment. Thus environmental management accounting could be extended to also include other sustainability issues as well. The challenge is to integrate the dimensions of sustainability - i.e. the economic, environmental and social dimensions. For some interesting discussion of the dimensions of sustainability and how these relate to business companies see e.g. Reid (1995) or Welford (1995). An early indication of that this is important for management accounting as well can be seen from the papers 
included in Bennett and James (1999) in which a number of the contributions address the need to broaden the scope of performance measurement towards sustainability issues (see. e.g. Ranganathan 1999). This trend has continued to grow and in 2004 the EMAN-EU network held a conference dedicated to the issue under the title Sustainability Accounting and Reporting ${ }^{1}$ in which a number of contributions addressed the need to broaden the scope of environmental management accounting. The prefix "environmental" might thus be to narrow to capture the future development of environmental management accounting and sustainability management accounting might be more appropriate. This trend is also apparent in external environmental reporting frameworks such as the Global Reporting I nitiative framework published in 2002 (GRI 2002) where social and financial issues are included as elements in what is called sustainability reporting.

On of the issues being addressed as part of the company's sustainability performance is Health and Safety (H\&S). H\&S as a function focuses on securing and promoting safety and health of the persons working for the company including both physical and mental health (Holt 2002). Like most other management function this includes developing and implementing $H \& S$ strategies, measuring and following up on performance issues and report these issues to internal and external stakeholders.

Ignoring Health and Safety can be expensive. Resulting effects such as occupational accidents cost money for the companies in which they happen, they lead to financial losses for the employees to whom they happen and they cost society money in e.g. health care and loss of working capacity. The European Agency for Safety and Health at Work has estimated that 4.6 million occupational accidents happen every year in the EU resulting in 146 million lost working hours (EU OSHA 2001). This means that approximately 2.6 to $3.8 \%$ of the collective EU Gross National Production (GNP) is lost every year. However, it seems logical that these costs might be avoided if these accidents could be prevented. Preventing occupational accidents should therefore make good economic sense for society as well as being good business practice to companies (Dorman 1997; 2000). Occupational accidents are generally defined as unforeseen sudden events that result in a physical injury to an employee (Dorman 2000).

Traditionally the information collected regarding occupational accidents has been e.g. frequency, types, location, employee groups, length of sick-leaves etc. This information has been put in relation with e.g. number of employees, numbers of hours worked, number of sites etc. (Holt 2002). However, when seeing H\&S issues and occupational accidents in an accounting context then the costs of these accidents, the value that the company looses in the course of occupational accidents and the value that is created though prevention initiatives becomes of interest.

\section{Approaches to measuring Health and Safety costs}

Evaluation of the business costs of occupational accidents has been the subject of numerous research projects in the past. Dating back to the 1920s a study by Herbert Heinrich documented that the costs of occupational accidents in American companies were substantial and that many costs were hidden from the view of management (Heinrich 1959). Following Heinrich's studies there have been many similar studies carried out in a number of countries (see e.g.: Grimaldi \& Simons 1984, HSMO 1993, Larsson \& Betts 1996, Monnery 1998). These studies document that there are can be significant costs associated with occupational accidents.

\footnotetext{
${ }^{1}$ For further information see http://www.eman-eu.net/
} 
The often stated reason for measuring H\&S costs is that if these costs are made explicit, then this will motivate managers to take $H \& S$ issues into account in their decision making. That is to say H\&S issues will become more business related and affect management decision making to a larger extent. However this is by no means certain. Consider these questions (see Aaltonen 1996):

1. Are H\&S costs significant in relation to other cost categories or turnover in the company or the department?

2. Can management affect H\&S costs through their actions?

3. Is the period between management action and the effect on $H \& S$ costs short enough so that managers can see the benefits of their actions?

4. Has management access to information about the effects of management initiatives on $\mathrm{H} \& S$ costs?

If the answers to some of these questions are negative then it is not certain that calculating $\mathrm{H} \& S$ costs will have an effect on management decision making.

$H \& S$ costs include a number of diverse issues but can be classified into two overall categories:

1. The costs of running an H\&S management system and the initiatives associated with promoting and securing H\&S in the company. These costs are usually relatively stable as they do not vary with the occurrence of negative effects such as occupational accidents and work related illness.

2. The costs of the consequences of e.g. occupational accidents or work related illnesses. These costs can be in for form of direct expenditures, raise in existing costs, potential reduction in income as well as opportunity costs. These costs vary with the type and number of consequences.

This categorisation is reflected in a number of studies of H\&S costs. Andreoni (1988) and HMSO (1993) use the terms prevention costs and accidents costs where prevention costs are not affected by individual accidents. This is somewhat comparable with the terminology used within quality costing systems (Dale \& Plunket 1997). It should be noted however, that some costs fall within both categories such as some insurance costs where there can be a fixed annual cost and a variable costs which increases as the insurance is used.

Consequence costs are like other costs in a company to a large extent contingency based - i.e. there is no general determinant of how high these costs are. Some of the factors affecting the costs of the consequences of occupational accidents are (based on Rikhardsson et al 2002; HMSO 1993; Dorman 2000):

1. Type of accident and length of absence: Industries differ regarding work characteristics and thus number and types of accidents. Companies in accidentprone industries are therefore more likely to have higher accident costs.

2. Wage structure and policies: A large portion of the total accident costs in each company is often sick pay during absence. However, this can vary according to the injured workers' position and wage, as well as structure of the social security system and local labor agreements. Danish companies for example are required by national law to pay full wages for the first 14 days after the accident. After 14 days the Danish social security system takes over but the rates are often lower than the full wages of employees. Thus some companies choose or were bound by union agreements to pay supplementary amounts to the employee so full wages were guaranteed for the whole duration of the sick leave. This meant that some companies had significantly higher costs of absence. Other countries such 
as USA and the UK do not have the same social security regulations which mean that the company either carries the costs itself or has to pay an insurance company to have them covered.

3. OHS management system scope: In larger companies the Occupational Health and Safety department is a staff function manned with a number of specialists and secretaries and functions under numerous policies, rules and regulations. Thus when an accident occurs in larger companies more formal activities are initiated than in smaller companies. There are more people involved, there are more internal administrative processes that have to be complied with and more organizational levels have to be informed.

4. Production process vulnerability: A very important determinant of occupational accident costs is what function the employee has in the company and how difficult it is to replace his or her function and competencies. If the employee is responsible for a key function in the production process or has key responsibilities and there is no immediate replacement available, then the accident costs are higher. Furthermore, in companies selling the work of their employees absent workers means lost revenues as well which has to be added to the total cost of the accident.

$H \& S$ cost studies there often fall into two categories (see e.g. Aaltonen et al 1996, Lanoie \& Trottier 1998, Söderquist et al. 1990):

1. Consequence studies: Evaluation of the costs of the consequences of negative $H \& S$ events such as occupational accidents.

2. Effect studies: Evaluation of the costs and benefits of implemented $H \& S$ measures

In the literature there is a predominance of studies within the first category. There are numerous effect studies about but very few have systematically focused on the economic consequences of $H \& S$ initiatives. Effects that are documented usually include e.g. reduction in sick days, number of occupational accidents, changes in attitudes towards safety measures etc.

Looking at consequence studies these can broadly be classified into two different approaches. Here these are called the insurance based approach and the activity based approach

The insurance based approach to consequence studies

The origins of the insurance based approach can be traced back to work done by Herbert Heinrich in the 1920s. Heinrich documented that the costs of occupational accidents in American companies were substantial and that many costs were hidden from the view of management (Heinrich 1959). Heinrich used data from insurance cases and divided costs into direct and indirect costs where the main classification criterion was whether these costs were refunded by the insurance. The costs that were not refunded by the insurance were termed indirect or hidden costs and were, according to Heinrich's study of selected occupational accidents, approximately $75 \%$ of the total costs of an average occupational accident. To express this distinction Heinrich developed the iceberg metaphor where the larger hidden part of the iceberg represented the indirect costs. One example of direct costs is e.g. sick pay and examples of indirect costs are e.g. the non-productive time of colleagues, administrative costs, production setbacks, replacement hiring costs, fines and investments in extra safety measures (Andreoni 1986). 
Using a similar methodological approach as Heinrich numerous studies have been carried out in a various countries. These studies document that there are significant costs, which are not insured in any way and constitute a loss to the company. However, the ratio between these costs is dependent on a number of contingency factors such as company size, accident type, industry, accident frequency etc. Monnery (1998), for example, documents that the ratio of insured and non-insured costs due to work related ill-health in a bank cheque clearing department constitute 1:3.3 - i.e. for every dollar covered by the insurance 3.3 dollars are not. A study conducted by the United Kingdom Occupational Health Authorities and published in 1993 documents different ratios ranging from 1:1 to $1: 11$ and depend on factors such as accident type, industry and company size. Other studies show similar conclusions (Grimaldi \& Simons 1984, Larsson $\&$ Betts 1996).

The common theme in these studies is the fact that they try in some way to distinguish between hidden and visible $\mathrm{H} \& S$ costs and usually apply the insurance criteria to do so. That is to say costs are analyzed in an insurance perspective and there is a lot of weight on what costs are refunded and what costs are not. This in turn often implies that the cost categories used are defined beforehand and often require some knowledge of insurance issues before they can be applied consistently across industries and companies. In some of the studies cited above this has meant that the analysis themselves is carried out by academics or outside consultants rather than by e.g. safety managers.

The activity based approach to consequence studies

In the 1970s and 1980s another approach to consequence studies emerges. In 1987 Laufer publishes a study of the costs of occupational accidents in which he distinguishes between controllable and non-controllable costs (Laufer $1987 \mathrm{a}$; b, see also Mossink 1997a, b; Pawlowska \& Rzepecki 1997; Thiehoff 1997; Leopold \& Leonard 1987; Wallach 1977; Zwetsloot \& Evers 1997). This marks the start of a more management oriented approach to consequence studies and has impact on empirical studies done by e.g. Söderquist (et al. 1990), Aaltonen (1996; 1997), Uusi-Rauva (et al. 1998) and Rikhardsson (et al 2002).

Thus the activity based approach has its focus on management and how management can use measurements of H\&S costs in their decision making to help to ultimately avoid these costs. Consequently there is more focus on involving management in these studies and developing tools and techniques that can be applied by management. Therefore, many activity based consequence studies are carried out in close cooperation with management. As insurance does not play as significant part in consequence based studies, management involvement is often cited in the literature as being more prominent.

The center of the activity based approach is the causality chain between the for example accident and the consequences of that accident which then are valued in economic terms. In the insurance based approach the costs is somewhat identical with the consequences of the event but the activity based approach focuses on the activities that happen after the event and the economic impact of those activities. Thus stringent costs categories are seldom used in the activity based approach, but the analysis is based upon documenting the activities that the event in question has led to and then evaluating the costs of these activities. Insurance as such does not play any a priori role in the activity based approach which leads to another distinction between visible and hidden costs. Activity based studies often do not apply the insurance criteria but base their distinction between hidden and visible costs on whether management has these costs readily available from the accounting systems of the company (see e.g. 
Rikhardsson et al 2002; Aaltonen 1998; Lanoi \& Trottier 1998; Aaltonen \& Miettinen 1997; Hinze 1991; Naquin 1975; Neville 1998).

The following section describes selected consequence based methods for estimating costs of accidents. It should be noted that these method only focus on the internal costs of companies and exclude e.g. social costs.

\section{Selected activity based methods for measuring H\&S costs}

\section{The Accident Consequence Tree (ACT) method}

The ACT method was first introduced in Uusi Rauva (et al. 1988) and in Aaltonen (1996; et al. 1996). The method focuses on the consequences an event like an occupational accident has on society, a company and the injured worker. The methodology assumes a common procedures for all three "payees" - i.e. that the event has consequences that prompt activities that have financial impact on the company. This basic chain of events that is captured by the ACT methodology is:

1. An event takes place

2. Consequences and activities are identified and registered in real time.

3. Consequences are quantified in e.g. number of hours, number of visits, quantity etc.

4. Unit prices of quantities are identified

5. Cost calculations.

The social costs are the direct costs that result from the accidents i.e. the costs of an ambulance trip, the costs of the doctors involved etc. The costs related to the injured worker include the reductions in income and any extra costs incurred by the worker or his/her family due to the accidents. The following will focus on the company costs.

There are 6 main categories used in the ACT method to classify consequences of e.g. occupational accidents. These are:

1. Lost working time which includes e.g. sick pay to the injured worked for which the company gets no work value in return, lost working time due to production disturbances etc.

2. Loss of short term assets: Loss of e.g. raw materials and products because of the event.

3. Loss of long term assets: Includes loss of e.g. machines or tools because of the event.

4. Diverse short term costs such as costs of transport, consultants and fines

5. Lost income such as lost contracts or price reductions

6. Income such as reimbursements from insurance companies

7. Other costs such as changes in insurance premiums.

Figure 1 shows an example of an accident tree based on Aaltonen (1996). 


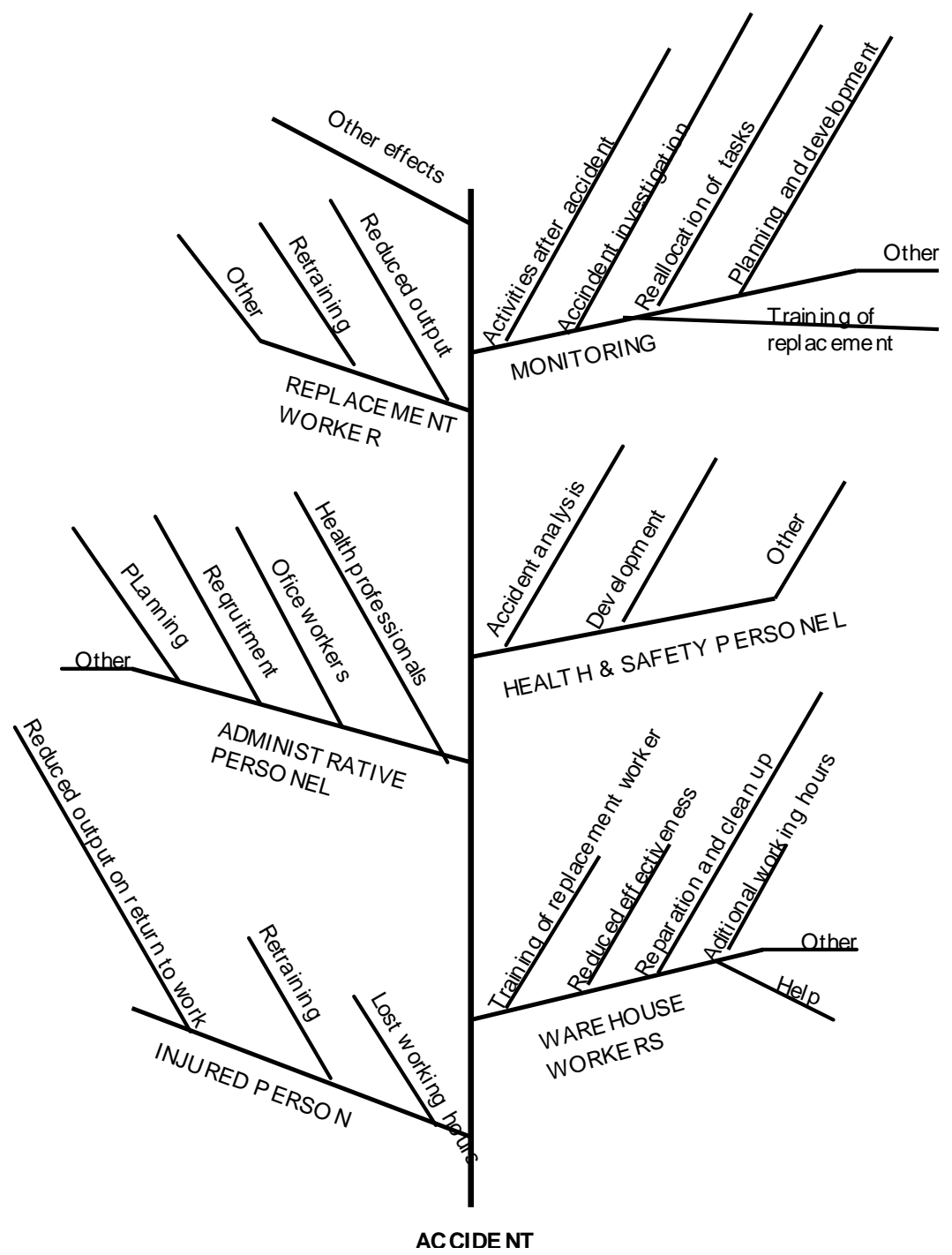

Figure 1: Example of an accident tree based on Aaltonen 1996.

One characteristic of the ACT method is that it occurs in real time - i.e. registrations of consequences and costs are made immediately after the accident occurs. Users are trained in the application of survey forms which are then used just as soon as the event being studied occurs. Usually it is foremen and middle managers who are trained in applying the ACT method over a period of time. This poses some challenges and methodological considerations. For example the method only looks at the events that take place during a certain period of time - for as long as the method is applied. If the application of the method is limited to one time period and if the events that occur in this period are atypical for the company then the results will be biased. Also the real time aspect of the method is dependent on the users of the method to actually fill out the forms when the event occurs. If this is not done then the results could become biased by forgetfulness and other events.

The method has been tested in the Scandinavian furniture industry where 214 occupational accidents in 18 companies were analysed (Aaltonen 1996; Söderquist et al 1990). The application resulted in average costs being calculated for occupational accidents at the societal, company and employee level. In all were 70 accident related consequences identified implying the loss of more than 9500 working hours. One of the conclusions of the studies using the ACT method was that costs of occupational 
accidents were markedly lower in companies where there were problems in producing the data. This might mean that costs of accidents are undervalued in companies where information about costs and consequences is not available.

The Riel and Imbeau ABC method

Riel and Imbeau (1995 a, b, c, d; 1996; 1998) base their method (here called the R\&I method) on the activity approach but in a somewhat different manner than the ACT method described above. Their method focuses on calculating accident costs with the purpose of using these costs as an allocation base for insurance costs. This is then used for evaluating the effects of ergonomic investments on insurance costs. This method thus combines to a degree both a consequence and an effect study. One issue is however, that the author's definition of "ergonomics" is rather broad and includes both workplace design as well as accident prevention measures.

Riel and I mbeau develop their method on the basis of Activity Based Costing (Kaplan \& Norton 1997). Activity based costing (ABC) reflects the same approach as the ACT method in that it values in financial terms the activities that are generated by an event. This application defines the event as a cost object and the measurements concern the resources that are consumed by the activities that are related to this event.

The method is based on the following stages:

1. Evaluation of H\&S costs. An important criterion is that the cost generated could have been avoided if the accident did not occur. These costs are evaluated through interviews and analysis of cost registrations.

2. Identification of cost behavior - i.e. the cost drivers and the causal relationships with the costs in question. The R\&l method distinguishes between three drivers which are resource drivers, activity drivers and cost drivers.

3. Cost allocation where the costs identified in stage 2 are used for allocating a cost pool which in the case of the $R \& l$ method are insurance costs but could in principle be any other type of cost provided there exists a causal relationship.

4. Cash flow calculations for the investment or initiative that is to be evaluated

5. Investment evaluation involving calculation of e.g. Return on Investment or Internal Rate of Return.

6. Investment evaluation which is carried out after the investment has been carried out and looks at weather the investment has been successful in relation to the chosen criteria.

When evaluating the costs of occupational accidents Riel \& I mbeau use a framework where costs of accidents are likened to production disturbances. The costs of these disturbances are classified into:

1. Over consumption of materials and assets - i.e. use of materials etc. which would not have taken place if the disturbance had not happened.

2. Over consumption of time - i.e. payment for employee time conducting activities that would not have been conducted if the disturbance had not taken place

3. Lost working hours - i.e. payment for working hours where no activities are carried out

4. Lost production - i.e. lost raw materials, capacity, products etc. due to the disturbance.

The R\&I method has been tested in an aerospace company in Canada where insurance costs where allocated between 6 departments on the basis of accident costs. Previously these insurance costs had not been allocated but accounted for as factory overhead. By allocating these costs on the basis of where the cost claims where generated the company was able to get a more accurate picture of the costs structures involved. 
The SACA method was developed by the Aarhus School of Business and PricewaterhouseCoopers in Denmark (see Rikhardsson et al. 2002; Rikhardsson \& Impgaard 2004; Rikhardsson 2004).

Being a consequence based methodology like the ACT and the R\&I method the SACA method focuses on the consequences of occupational accidents and the costs of these consequences. The main procedure is first identifying the activities generated by the occupational accident being analysed and the next step is calculating the costs of these to the company. There is no allocation of costs like in the R\&l method and there is solely focus on company costs and not on societies costs or the costs to the injured employee like in the ACT method.

The SACA method is based on a number of forms and checklists which are intended for guidance only. The main aim of the method is to provide managers with a tool for identifying accidents costs without them having to have a lot of experience in accounting or financial analysis to be able to do so. The method is based on interviews and workshops and is not intended to be used in real time.

The costs of occupational accidents are classified into six overall categories:

1. Costs due to the absence of the injured employee: Includes e.g. payment of sick pay and payment of supplementary sick pay.

2. Communication costs: Includes e.g. formal communication to employees, staff, and general management as well as informal communication between employees.

3. Administration costs: Includes payroll administration, administration regarding health and safety regulations and reporting requirements, follow-up activities and meetings.

4. Costs of prevention initiatives: Includes e.g. purchase of machine components and training initiatives.

5. Operation disturbance costs: Includes e.g. training of replacements, revenue loss, co-workers overtime, and production reductions.

6. Other costs: Includes costs such as e.g. fines and gifts to injured employee.

The actual costs measured within these categories are grouped into four categories:

1. Time: Hours used by employees and management on activities related to the accident as well as hours for which the company pays wages without getting any work effort in return including standstill periods in production and employee sick pay.

2. Materials and components: Costs of any materials and components acquired or lost due to the accident such as spare part for machines, replacement for damaged materials, and value of products not produced.

3. External services: Costs of external services bought due to the accident such as temporary replacements, consultants and legal support

4. Other costs: Costs of other activities more infrequently incurred by the company such as fines and rehabilitation.

The method has been tested in a number of companies (Rikhardson \& Impgaard 2004; Rikhardsson et al. 2002) in relation to different accident types and contexts. The main results were that:

1. Calculating occupational accident costs can illustrate and visualize the value created by the OHS department by preventing accidents. 
2. The costs of occupational accidents in a company can be significant depending on the type of accident, sick leave payments, and how the accident affects e.g. the production process and the scope of administration and information activities.

3. Accident costs vary between companies and depend on accident type, wage structures and policies, OHS management system scope, and production process vulnerability.

4. Smaller companies had on the average higher accident costs per accident than larger companies.

5. Hidden accident costs, defined after their visibility in the accounting information system, amounted to $35 \%$ of the total accident costs on the average. This could vary from $2 \%-98 \%$ depending on accident characteristics.

The Health \& Safety Executive (HSE) method

The method is developed by the Health \& Safety Executive in the UK in the early 1990s (HMSO 1993). As such it differs from the three methods above as is more focused on insurance costs and uses the insurance criterion to distinguish between hidden and visible costs. Furthermore, it not only includes H\&S costs but focuses on material damage costs as well even though no injury is associated with this damage. The cost definitions of the HSE method are shown in figure 2. It distinguishes between direct and indirect costs which may or may not be refunded by the company insurance.

Furthermore, the method is applied in real time like the ACT method.

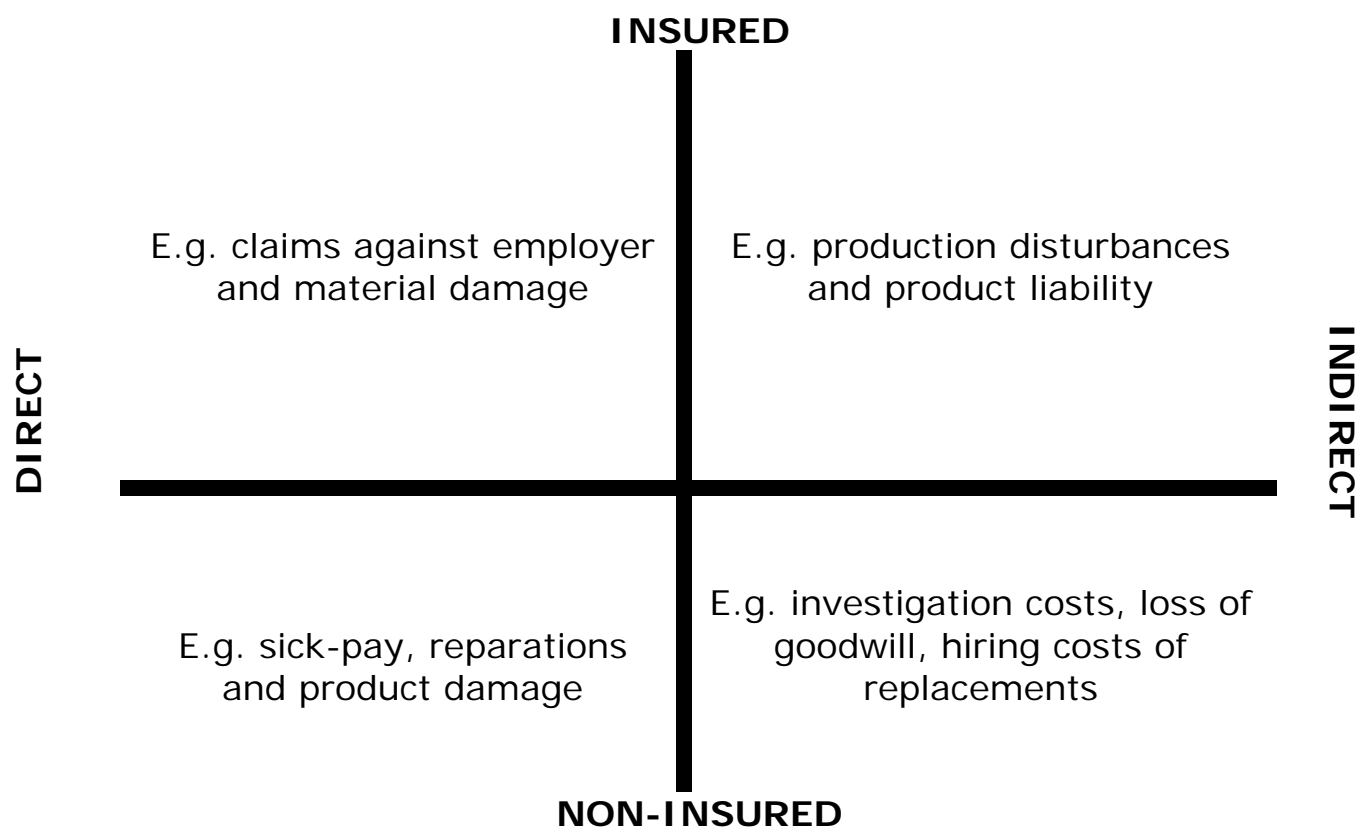

Figure 2: The cost classification used in the HSE method (HMSO 1993)

The method also distinguished between what it terms financial costs and opportunity costs. Financial costs are defined as the costs incurred due to the necessary activities resulting from the accident and opportunity costs are costs for which the company gets no value in return. This is not quite the usual accounting definition of the term opportunity costs and the term non-value added costs might have been more appropriate. The method also stresses that only costs which could have been avoided if the accident had not happened should be registered. 
The method has been tested on a number of companies in the UK where the main focus was calculating the total costs of accidents in the selected period and calculating the ratio between insured and non insured costs. These ratios varied from 1:8 to 1:36. These costs also included material damage which in some cases was a significant part of the total cost.

One of the most comprehensive uses of the method took place in a construction company where the total accident costs were calculated to be $£ 700.000$ which amounted to $8,5 \%$ of the total contract fee of the building site investigated. In all were 3500 material damage incidents and 56 occupational accidents registered. The ratio between insured costs and non-insured costs was $1: 11$. That is to say for every $£ 1$ that was refunded from the insurance company a cost of $f 11$ was generated that was not refunded.

\section{Comparison of the selected methods}

The four methods described above are compared in general terms in table 1.

\begin{tabular}{|c|c|c|c|c|}
\hline & ACT & $\mathbf{R} \& \mathbf{I}$ & SACA & HSE \\
\hline $\begin{array}{l}\text { Year } \\
\text { developed? }\end{array}$ & 1986 & 1995 & 2002 & 1993 \\
\hline Primary focus & $\begin{array}{l}\text { Costs of } \\
\text { occupational } \\
\text { accidents for } \\
\text { society, } \\
\text { companies and } \\
\text { injured persons }\end{array}$ & $\begin{array}{l}\text { Costs of } \\
\text { occupational } \\
\text { accidents } \\
\text { Allocation of } \\
\text { insurance costs } \\
\text { Ergonomic } \\
\text { investment } \\
\text { evaluations }\end{array}$ & $\begin{array}{l}\text { Costs of } \\
\text { occupational } \\
\text { accidents }\end{array}$ & $\begin{array}{l}\text { Costs of } \\
\text { occupational } \\
\text { accidents } \\
\text { Material } \\
\text { damage }\end{array}$ \\
\hline $\begin{array}{l}\text { Basic } \\
\text { measurements }\end{array}$ & $\begin{array}{l}\text { Consequences } \\
\text { and activities }\end{array}$ & $\begin{array}{l}\text { Consequences } \\
\text { and activities }\end{array}$ & $\begin{array}{l}\text { Consequences } \\
\text { and activities }\end{array}$ & $\begin{array}{l}\text { Consequences } \\
\text { and activities }\end{array}$ \\
\hline Application & Real time & Post hoc & Post hoc & Real time \\
\hline $\begin{array}{l}\text { Assumed level } \\
\text { of accounting } \\
\text { skills required }^{2}\end{array}$ & Low & High & Low & Middle \\
\hline $\begin{array}{l}\text { Extensive } \\
\text { methodological } \\
\text { descriptions } \\
\text { and checklists } \\
\text { available }\end{array}$ & No & No & Yes & Yes \\
\hline
\end{tabular}

Table 1: General comparison of the selected methods

Another way of comparing the methods is assessing their strength and weaknesses which is shown in table 2. It should be noted that this assessment is subjective and based on an evaluation of the methodological descriptions and cases detailing the experiences of the companies that have applied the methods.

\begin{tabular}{|l|l|l|l|l|}
\hline & ACT & R\&l & SACA & HSE \\
\hline $\begin{array}{l}\text { Potential } \\
\text { strengths }\end{array}$ & $\begin{array}{l}\text { Can potentially } \\
\text { be integrated }\end{array}$ & $\begin{array}{l}\text { Incorporates } \\
\text { newer }\end{array}$ & $\begin{array}{l}\text { Simple non- } \\
\text { accounting }\end{array}$ & $\begin{array}{l}\text { Can be } \\
\text { integrated into }\end{array}$ \\
\hline
\end{tabular}

${ }^{2}$ This is a subjective evaluation by the author of this chapter 


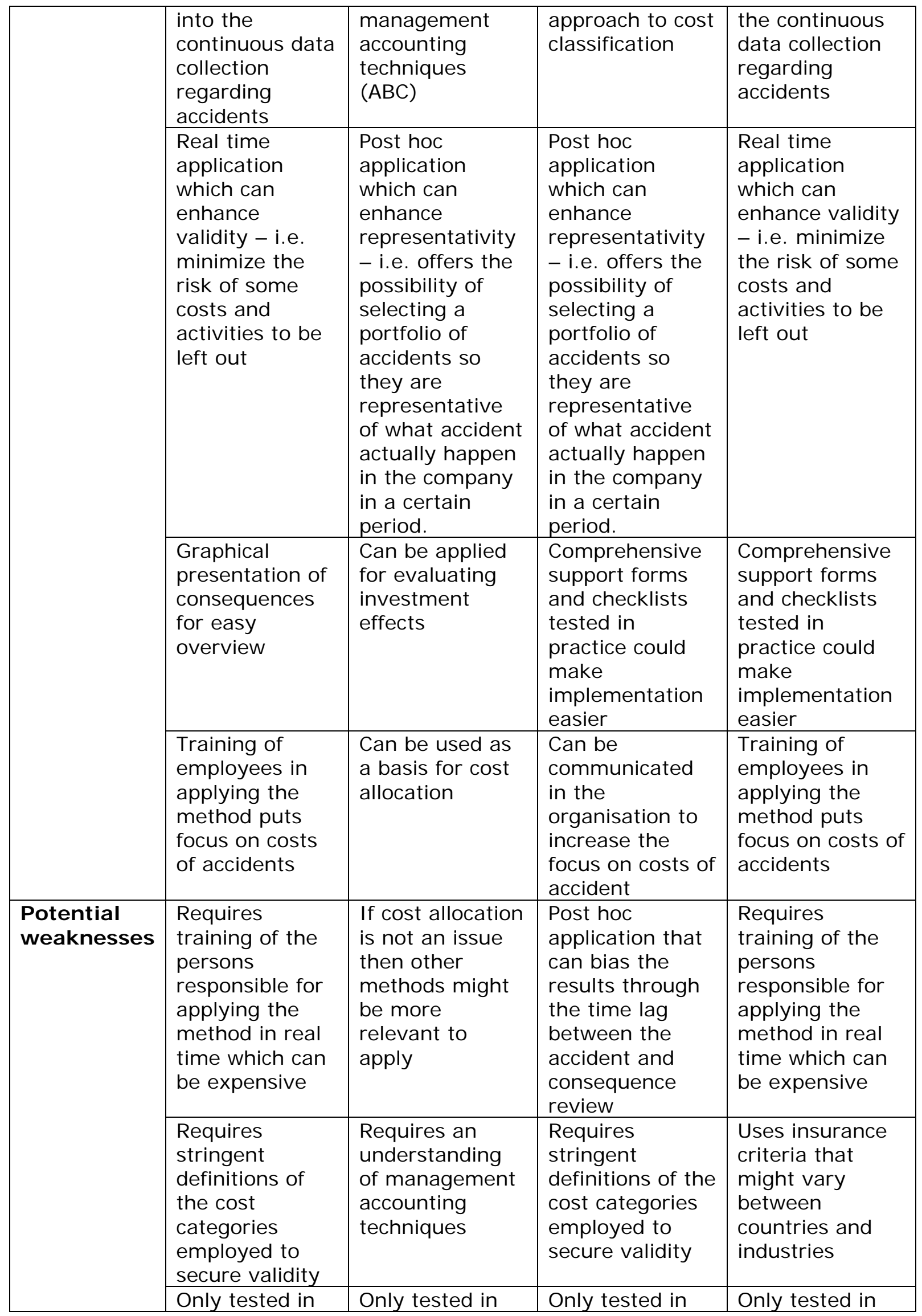




\begin{tabular}{|c|c|c|c|c|}
\hline & $\begin{array}{l}\text { Scandinavian } \\
\text { companies }\end{array}$ & $\begin{array}{l}\text { few Canadian } \\
\text { companies }\end{array}$ & $\begin{array}{l}\text { Danish } \\
\text { companies }\end{array}$ & UK companies \\
\hline & $\begin{array}{l}\text { Focuses only on } \\
\text { a limited period } \\
\text { and the } \\
\text { accident } \\
\text { occurring in } \\
\text { that period } \\
\text { which might } \\
\text { threaten } \\
\text { validity. Also } \\
\text { real time } \\
\text { registration } \\
\text { might not } \\
\text { capture costs } \\
\text { that emerge } \\
\text { some time after } \\
\text { the accident. }\end{array}$ & $\begin{array}{l}\text { Registers } \\
\text { consequences } \\
\text { some time after } \\
\text { the accident } \\
\text { occurs which } \\
\text { could lead to } \\
\text { bias due to } \\
\text { forgetfulness or } \\
\text { subjective } \\
\text { interpretations }\end{array}$ & $\begin{array}{l}\text { Registers } \\
\text { consequences } \\
\text { some time after } \\
\text { the accident } \\
\text { occurs which } \\
\text { could lead to } \\
\text { bias due to } \\
\text { forgetfulness or } \\
\text { subjective } \\
\text { interpretations }\end{array}$ & $\begin{array}{l}\text { Focuses only on } \\
\text { a limited period } \\
\text { and the accident } \\
\text { occurring in that } \\
\text { period which } \\
\text { might threaten } \\
\text { validity. Also } \\
\text { real time } \\
\text { registration } \\
\text { might not } \\
\text { capture costs } \\
\text { that emerge } \\
\text { some time after } \\
\text { the accident. }\end{array}$ \\
\hline
\end{tabular}

Table 2: Potential strengths and weaknesses of the different methods.

In general there are a number of issues that have to be considered when choosing and applying a method for measuring costs of occupational accidents. These issues are discussed below.

\section{Definition of H\&S costs}

One of the dimensions separating the methods in question and which is important to consider for a company wanting to apply a method is the definition of $H \& S$ costs. Is the method focused on company costs or does it include societal and employee costs as well? Is the company interested in calculating the costs of occupational accidents, occupational illness, damage to materials, assets etc. or all of these? Regarding costs of work related illness quite few methods have focused on systematically calculating the costs of occupational illnesses. One of these applied the HSE method for calculating the costs of several work related illnesses in the UK water supply companies (IRS 1999). This survey showed that measuring the costs of occupational accidents can be difficult to measure because of long time periods, unclear causal relations, unclear consequences and thus indefinable costs.

Regarding material costs - i.e. costs not related to injured persons - it is worth considering whether these are to be included in the calculations of H\&S costs. These costs can often be high compared to the direct costs of the accident itself and thus bias the total costs calculated. The causal relationships might also be difficult to untangle as well if the e.g. accident is due to second or third stage effects of a material damage that even might be distant in time and space. The argument for including material damage however can be based on the so called accident pyramid, which is another of Heinrichs influential metaphors (Heinrich 1959). This metaphor states that for every occupational accident leading to serious injury there are a certain number of accidents not leading to serious injury and for every one of those there are a even greater number of accidents leading to material damage accidents - thus the pyramid metaphor. So the total costs of material damage might tell decision makers something about the potential for accidents involving persons and what value is created through avoided costs by preventing material damage. 


\section{Definition of cost categories}

All methods focusing on costs of occupational accidents have some sort of a distinction between direct and indirect costs. Most methods are alike in that direct costs are considered visible in some way while indirect costs are in some way hidden from management view. There is however a difference between how this visibility criteria is defined. Some of the methods and resulting studies are based on Heinrich's methodology. These use insurance refunds as criteria for visibility i.e. costs that are covered by the insurance are defined as direct and visible but costs not covered are defined as indirect ad hidden. This might however, not always be relevant for companies that want to monitor their e.g. accident costs and use this as input to management decision making due to the fact that insurance coverage is not used when the costs are registered as such in the company accounting system. Other methods like the SACA method have thus used the accounting system as criteria for when costs are visible and when they are not. That is to say the costs that are defined as visible in the accounting system are accounted for in such a way that they are traceable to the accident in question and can thus be identified and pulled out of the accounting system with a minimum of work. Other costs - i.e. the hidden ones - are registered in overhead accounts or other cost pools and thus hidden from view. These costs have to be "carved out" of these accounts by applying e.g. a consequence based analysis such as the one used in the SACA or the ACT method (Rikhardsson \& Impgaard 2004). It might be argued that these types of methods are more practical if insurance coverage is not an important issue and the focus is on management usability of the information generated.

\section{Data collection procedures}

The data collection procedure used in the methods is either data collection in real time i.e. immediately following the accident and as activities and consequences unfold or post hoc i.e. some time after the accident has taken place. These approaches have their benefits and drawbacks. Methods employing the real time approach are based on someone registering the consequences of e.g. accidents at the same time they occur. This implies training of e.g. foremen or other employees in applying the forms needed to register the information. Also it presupposes that those responsible for registering the information do so in a timely manner. The benefits of this are e.g. that there is strong focus on the registration of consequences and cost data in a period and that most consequences are registered and accounted for. The potential drawbacks are that the persons involved might not in time register the consequences due to oversight, not recognizing the consequences as being related to the accident, due to not understanding the method or because the accident itself takes focus away from applying the method. Another drawback is that real time methods are dependent on the types of accidents occurring in the period they are applied. If the intention is to generalize about the total accident costs of the company and the company in the period examined doers not experience any serious accidents or that if the accidents that occur are significantly different from the accidents that usually occur then this might bias the results and lead to the wrong conclusions being drawn regarding the total accident costs of the company.

Methods using post hoc data collection approaches use interviews and workshops to collect information some time after the accident has taken place. The benefit is that these workshops or interviews are independent of the accidents. A representative sample of accidents can be selected so that the average costs can reflect e.g. different accident types, time periods and locations. Furthermore, the accident is not as emotionally near those involved so that other aspects and consequences can be identified than those that are immediately apparent when the accident occurs. The 
drawbacks are that forgetfulness or different interpretations of events can create omissions or bias.

From loss management to value creation

In the literature surrounding the methods described above there is a certain trend where the loss management perspective inherent in these methods is developed further. Loss management as an H\&S perspective is traditionally focused on minimising the risk of accidents happening through e.g. prevention initiatives, training and control. As such this is seen as a cost is in self as these H\&S initiatives cost money. However, a company creates value for a number of stakeholders. It creates (economic) value for e.g. customers, suppliers, for employees, for owners and for society. A company can thus be seen as a collection of resources focused on creating value. When a negative event like an occupational accident happens then value is lost or the ability of the company to create value is lost. This perspective broadens the focus of loss management somewhat. If e.g. prevention initiatives are viewed in this perspective then they not only minimise the risk of an accident happening in the future but also prevent economic value from being lost then the value of these initiatives are automatically made visible through the identification of costs.

\section{Conclusions}

Comparing the four methods above indicates that a company might want to assess the purpose of it wanting to calculate accident costs. Is it to increase visibility, enhance decision making, a vehicle for increasing employee or management focus on costs, for evaluating accident prevention initiatives or is it for making cost allocations more precise? Whatever the reason the four methods above have their strengths and weaknesses that might have to be assessed by the company.

Another conclusion is that methods for calculating accident costs are evolving in a similar manner as management accounting is evolving (Read 2003). That is to say there is an increasing focus on value creation, on activity costs and on usefulness for management decision making. Given that this increases the focus on the prevention of accident as a value creating activity then this evolution can only be termed as positive.

Future research challenges for further evolving the calculation of H\&S costs generally could be:

1. Systematically evaluating any changes in practices of companies that have applied the methods described above regarding e.g. increased focus on accident prevention, changed management behaviour etc.

2. Evolving these methods further towards calculating the costs of other H\&S issues such as work related illness, mental work environment etc.

3. Identifying how and if the integrated IT systems (ERP systems) currently being implemented in many companies can support the calculation of H\&S costs.

4. Most of the methods have only been applied on a country specific and company specific basis. It could be interesting to conduct a representative study of accident costs across countries and across different industry segments.

\section{References}

Aaltonen, M. V.P; Uusi-Rauva, E. ; Saari, J. ; Räsänen, T. Antti-Poika, M.; Vinni, K. (1996). The Accident Consequence Tree Method and its Application by Real-Time Data Collection in the Finnish Furniture Industry. Safety Science, Vol. 
23, No. 1, pp. 11-26.

Aaltonen, M.V.P. (1996). A Consequence and Cost Analysis of Occupational Accidents in the Furniture Industry. Doctoral Dissertation. People and Work 6. Finnish Institute of Occupational Health, Helsinki.

Aaltonen, M.V.P. (1997). Costs of Accidents. In D. Brune, G. Gerhardsson, Grokford, G.; Norbäck, D. (Eds.). The Workplace, Vol. 1 Fundamentals of Health, Safety and Welfare. Scandinavia Scientific Press, Oslo, p. 244-256.

Aaltonen, M.V.P.; Miettinen, J. (1997).Computer Aided Calculation of Accident Costs. International J ournal of Human Factors in Manufacturing, Vol. 7, (2), p. 67-78.

Andreoni, D. (1986). The Cost of Occupational Accidents and Diseases. International Labour Office, Geneva.

Atkinson, A., R. Banker, R. Kaplan, S. M. Young (2004). Management Accounting. New York: Prentice Hall.

Bartolomeo, M. , M. Bennett, J. J. Bouma , P. Heydkamp , P. James , F. De Walle, T. Wolters (1999). Eco-Management Accounting: Based upon the Ecomac Research Project Sponsored by the Eu's Environment \& Climate Programme. Dordrecht (NL): Kluwer Academic Publishers.

Bennett, M. and P. James 1998, The Green Bottom Line. In The Green Bottom Line. Environmental Accounting for Management. Current Practice and Future Trends. Sheffield, UK: Greenleaf.

Bennett, M. and P. James, 1999 (Eds.) Sustainable Measures. Evaluation and Reporting of Environmental and Social Performance. Sheffield, UK: Greenleaf.

Dale, B. G.; Plunkett, J. J. (1997). Quality Costing. London: Chapman \& Hall.

Dorman, P. (1997). Internalizing the Costs of Occupational Injuries and Illnesses: Challenge or Chimera? Proceedings of the European Conference on Costs and Benefits of Occupational Safety and Health, Hague.

Dorman, P. (2000). The Economics of Safety, Health and Well-being at Work: An Overview. In Focus Program on SafeWork, International Labour Organisation. The Evergreen State College. From www.ilo.org.

EMAN (2004). Proceedings: Sustainability Accounting and Reporting - The 7th annual conference of the Environmental Management Accounting Network Europe (EMAN-EU). Available from www.eman-eu.net.

EU OSHA (2001) EU European Agency for Health and Safety at Work. Economic Impact of Occupational Safety and Health in the Member States of the European Union. European Agency for Safety and Health at Work.

GRI (Global Reporting I nitiative) (2000). Sustainability Reporting Guidelines on Economic, Environmental and Social Performance. Boston: GRI:

http://www.globalreporting.org.

Grimaldi, J. V.; Simonds, R.H. (1984). Safety Management. New York: Richard 


\section{Irwin.}

Heinrich, H. W. (1959). Industrial Accident Prevention. A Scientific Approach. McGraw-Hill, New York, $4^{\text {th }}$ edition.

Hinze, J. (1991). Indirect Costs of Construction Accidents, Austin: Construction Industry Institute.

HMSO (1993). The Cost of Accidents at Work. HMSO, London.

Holt, A. J. (2002). Principles of Health and Safety at Work Wigston, Leicestershire, UK: IOSH Services Ltd.

IRS Employment Review (1999). Measuring the cost of work related ill health in the water industry. IRS Employment Review pp. 14-16.

Kaplan, R. S. \& D. N. Norton (1997). Cost \& Effect: Using Integrated Cost Systems to Drive Profitability and Performanc. Harvard: HBS Press.

Lanoie, P.; Trottier, L. (1998). Cost and Benefits of Preventing Workplace Accidents: Going from a Mechanical to a Manual Handling System. J ournal of Safety Research, Vol. 29, No. 2.

Larsson, T.J .; Betts, N.J. (1996). The Variation of Occupational injury Cost in Australia; Estimates Based on a Small Empirical Study. Safety Science, Vol. 24, No. 2, pp. 143-155.

Laufer, A. (1987). Construction Safety: Economics, Information and

Management Involvement. Construction Management and Economics, 5, pp. 73-90.

Laufer, A. (1987). Construction, Accident Costs and Management Safety Motivation. Journal of Occupational Accident, 8, pp. 295-315.

Leopold, E.; Leonard, S. (1987). Costs of Construction Accidents to Employers. J ournal of Occupational Accident, 8, pp. 273-294.

Monnery, N. (1998). The costs of accidents and work-related ill health to a cheque-clearing department of a financial services organisation. Safety Science 31, pp. 59-69.

Mossink, J. (1997a). Impact on business, the productivity of working conditions. I Proceedings of the European Conference on Costs and Benefits of Occupational Safety and Health, Hague.

Mossink, J. (1997b). Instruments and models to assess cost and benefits at the company level. I Proceedings of the European Conference on Costs and Benefits of Occupational Safety and Health, Hague.

Naquin, A. J. (1975). The Hidden Costs of Accidents. Prof. Safety, 20, pp. 3639.

Neely, A (ed.) (2003) Business performance measurement: Theory and practice Cambridge: Cambridge University Press. 
Neville, H. (1998). Workplace Accidents: they cost more than you think. Industrial Management, Vol. 40, No. 1, pp. 7-10.

Pawlowska, Z.; Rzepecki, J. (1997). The proposed method of calculating the cost of occupational accidents in the company. Proceedings of the European Conference on Costs and Benefits of Occupational Safety and Health, Hague.

Poston, R. \& S. Grabski (2001). Financial Impacts of Enterprise Resource Planning I mplementations. International J ournal of Accounting Information Systems. (2), pp. $271-294$.

Ranganathan, J. (1998). Signs of Sustainability: Measuring Corporate Environmental and Social Performance. In Bennett, M. and P. James, 1999 (Eds.) Sustainable Measures. Evaluation and Reporting of Environmental and Social Performance. Sheffield, UK: Greenleaf.

Read, C. (2003). The CFO as Business Integrator New York: J ohn Wiley and Sons Ltd.

Reid, D. (1995). Sustainable Development - An Introductory Guide. Earthscan Publication Ltd, London.

Riel, P.; Imbeau, D. (1995a). Applying ABC to Ergonomic and Safety Costs. Proceedings of the $46^{\text {th }}$ International Industrial Engineering 2 (1), 1995.

Riel, P.; I mbeau, D. (1995b). Economic Justification of investments for Health and Safety Interventions-Part 1: A cost Typology. International J ournal of Industrial Engineering, 2 (1).

Riel, P.; I mbeau, D. (1995c). Economic Justification of investments for Health and Safety Interventions-Part 2: Applying Activity Based Costing to the Insurance Cost. International J ournal of Industrial Engineering, 2 (1).

Riel, P.; I mbeau, D. (1995d). Making the best ergonomics investment. Institute of Industrial Engineers, Vol. 27, Issue 6, pp. 30.

Riel, P.; I mbeau, D. (1996). Justifying investments in industrial ergonomics. International J ournal Of Industrial Ergonomics 18, pp. 349-361.

Riel, P.; Imbeau, D. (1998). How to Allocate the Health and Safety Insurance Cost Within the Firm. Journal of Safety Research, Vol. 29, No. 1, pp. 25-34.

Rikhardsson, P. \& M. Impgaard (2004). Corporate Cost of Occupational Accidents: An Activity Based Analysis. Journal of Accident Analysis and Prevention Volume 36, Issue 2, pp 173-182.

Rikhardsson, P. (2004). Accounting for the Costs of Occupational Accidents. In Corporate Social Responsibility and Environmental Management 11(4), pp. 6370.

Rikhardsson, P., M. Impgaard, B. Mogensen, A. Melchiorsen (2002). Virksomhedens Ulykkesomkostninger (Cost ofr Occupational Accidents in Companies). Aarhus (DK): The Aarhus School of Business and PricewaterhouseCoopers. Available in Danish only. Free copy can be ordered 
from par@asb.dk.

Söderqvist, A.; Rundmo, T.; Aaltonen, M. (1990) Costs of Occupational Accidents in the Nordic Furniture Industry (Sweden, Norway, Finland). Journal of Occupational Accident 12, pp.79-88.

Thiehoff, R. (1997). Occupational Safety \& Health as a Competitive Factor. Proceedings of the European Conference on Costs and Benefits of Occupational Safety and Health, Hague.

Uusi-Rauva, E. ; Aaltonen, M. V.P; Saari, J. ; (1988). The Method for Evaluating the Accident Consequence Costs at Company Level. TETA Report 105. Helsinki University of Technology, Laboratory of Industrial Economics.

Wallach, M.B. (1977). Accident Costs - A New Concept. American Society of Safety Engineers J ournal, pp. 25-26.

Welford, R. (1995) Environmental Strategy and Sustainable Development - The Corporate Challenge for the $21^{\text {st }}$ Century. London: Routledge.

Zwetsloot, G.; Evers, G. (1997). The added Value of Total Health \& Safety Management. Proceedings of the European Conference on Costs and Benefits of Occupational Safety and Health, Hague. 


\section{Working Papers from Management Accounting Research Group}

M-2005-06 Pall Rikhardsson: Accounting for Health and Safety costs: Review and comparison of selected methods.

M-2005-05 Pall Rikhardsson, Carsten Rohde \& Anders Rom: Exploring Enterprise Systems and Management Control in the Information Society: Developing a Conceptual Framework.

M-2005-04 Jesper Thyssen, Poul Israelsen \& Brian Jørgensen: Activity Based Costing as a method for assessing the economics of modularization - a case study and beyond.

M-2005-03 Christian Nielsen: Modelling transparency: A research note on accepting a new paradigm in business reporting.

M-2005-02 Pall Rikhardsson \& Claus Holm: Do as you say - Say as you do: Measuring the actual use of environmental information in investment decisions.

M-2005-01 Christian Nielsen: Rapporteringskløften: En empirisk undersøgelse af forskellen imellem virksomheders og kapitalmarkedets prioritering af supplerende informationer.

M-2004-03 Christian Nielsen: Through the eyes of analysts: a content analysis of analyst report narratives.

M-2004-02 Christian Nielsen: The supply of new reporting - plethora or pertinent.

M-2004-01 Christian Nielsen: Business reporting: how transparency becomes a justification mechanism. 
ISBN 87-7882-081-2

Department of Accounting, Finance and Logistics

Aarhus School of Business

Fuglesangs Allé 4

DK-8210 Aarhus V - Denmark

Tel. +4589486688

Fax +4586150188

www.asb.dk 